\title{
A Program of In-Service Training in College and University Libraries
}

$\mathrm{T}$ HIS PAPER is concerned with the development of a library program directed at encouraging the personal and professional growth of staff members. The program offered here is concerned with the literature of subject fields and with the authors and the place of their books which have contributed to the intellectual development of the race. These books are sufficient in number to permit of varied choice and interests and yet not too numerous to discourage a selection that would be suitable for the purpose and manageable in relation to the amount of time possible to devote to a program of mapping out the field, of reading, and of discussion. The plan proposed is for college and university libraries. A selection of the literatures of the physical sciences, the biological sciences, the social sciences, and the humanities proyides the content for the course.

Raymond Pearl, in the introduction to his famous annotated list of great books that biologists should read and know, entitled To Begin With, recognized a lack of bibliographic knowledge in his graduate students and advocated that the serious gap in students' knowledge of books covering a wide range should be bridged, and recommended as a means a course of directed reading. His book is a valuable aid in such a course designed for librarians as well as for biologists or any other subject specialists.

\footnotetext{
1 Abridgement of a paper presented at the joint meeting of the American Association of Library Schools and the Professional Training Round Table, Buffalo, June 21, 1946. Miss Fay, before going to Temple University, was associate professor in the School of Library Service, Columbia University.
}

Dr. Pearl's suggestion of remedy was met by biologists with the same lethargy and do-nothingness as university and college librarians have shown toward a program of staff group-study.

The first reason, then, for developing a program of in-service training is the lack of acquaintance by librarians with one of the two elements they deal with-books. The second and more important elementpeople - is also a reason for such a study. The students and faculty in colleges and universities expect and have a right to demand intelligent service in their libraries. For students this service includes guidance in reading as well as in the use of books and library tools. For faculty members, intelligent service means a sufficient acquaintance on the part of the staff with the book sources of major subject fields to be able to meet faculty requests with understanding and sympathy in the research that is being done. This sounds perfectly obvious, but the plain truth is that college and university library staffs are not now equipped to do this. How often do we hear the sort of criticism of librarians' lack of a knowledge of books voiced by Jacques Barzun at the Eastern Librarians' Conference in 1945 and before that in his Teacher in America? Much of such comment is not justified, but similar criticism is sometimes unfortunately too true.

A third purpose of this serious effort to capture or recapture a knowledge of the books that have and are profoundly molding civilization, is to gain the respect of faculty 
members for the library staff's acquaintance with the contents of books. They already respect us for our technical knowledge of the physical aspects of books. Faculties do not grow intellectually without their planned programs of investigation and research; neither will college library staffs. There must be both individual study and group study.

A staff' study program affords a useful and illuminating means of evaluating the qualifications and abilities of staff members and is therefore an important element in personnel management and development.

Without adding other reasons for such a program, there might be considered one more essential element that usually stems and grows from such a group-study planenlightened and enlarged professional interests. It is a fact that a college library staff begins to realize, from such study and effort, what the educational goals of the college are and the part the library may and should play in training students, generation after generation, over and above the formal class instruction received. That vision once caught, there opens up the broad view of what librarianship in America can achieve in the field of liberal education. The opportunity is tremendous; can we forget our inertia and, on the part of some, our cynicism and really develop within us the will to do? Such study will not make anyone an authority in the subject knowledge of a field, nor would a goal of perfection be possible of attainment. Notwithstanding, librarians make that impossibility an excuse for doing nothing.

\section{Developing a Program}

It is one thing to see the need of any kind of program of education and quite another proposition to plan a workable schedule and an acceptable and worth-while content. Some suggestions are here of- fered for planning a staff group-study program:

I. Begin with a modest plan that will grow. as the staff's interest grows.

2. Consult with heads of the library divisions on - the project. They must believe in it and be willing to aid in planning and executing.

3. If the idea is accepted, a committee should be appointed to plan and carry out the scheduled program.

4. Monthly staff meetings from October to May can be devoted to this study program, cabinet meetings of heads of divisions being used for discussion of policies, technical matters, etc.

5. Some library time must be allotted to each participant for this study, the amount determined in each library. The staff member should give an equal amount of his own time. At Temple a staff member is allowed three hours a week of library time to attend a course in the university. His preparation must be done on his own time. The results have shown that this policy has been justified and not abused. The same time allowance could be made for group-study but not in the same year that an assistant was taking a course in the university.

6. With a large staff it will probably be necessary to divide into smaller groups. In that case, the division should be such that each group would contain both able and timid members. Those staff members that have the quality of leadership should be given the responsibility of directing and guiding the discussions. As a preparation for this, these discussion leaders should get training for the work as was done by the University of Chicago in its community group-studies of great books.

7. Such a plan of study will be more successful if it grows out of staff initiative and interest and is not imposed from above. It is not likely that there can be any standardization of in-service training of this kind. Each library must develop its own standards according to its needs.

\section{A Practical Approach}

Recently the writer had occasion to look over the outlines and lesson plans of a semester's course on book selection for col- 
lege libraries which she offered at the New York State Library School, Albany, in 1925-26. Under date of Feb. 10, 1926, in the outline under "Methods," were listed the following steps for consideration and discussion:

I. Each head of a department in a college library or any member of the staff should specialize in a particular subject: history, zoology, agriculture, the classics, a modern language, economics, etc.

2. How shall we acquire a knowledge of the literature of these subjects?

a. By reading the history of the subject

b. By studying the subject bibliographies

c. By studying the curricula of these subjects as given in college catalogs.

3. Map out the territory: e.g., in a foreign language: authors (individual), texts, annotated texts, translations, collateral or auxiliary subjects.

4. Compare with the library collection, check for gaps, weed out.

This was the germ of what was two years later (1928) developed at Columbia as a plan of study for the course in college and university libraries, with the idea that students going back to their libraries might continue to use it as a plan of continuing education in subject literature fields. In the more developed form it is offered here by way of suggestion. ${ }^{2}$

When the subject field for a year's study has been selected, say, the literature of the physical sciences or the biological sciences or the social sciences or the humanities or a specific area from any one field, begin by (I) examining the best outlines and charts of the content of the field; (2) read a history of the subject, the best one from the standpoint of authority and yet not too long or technically written a text; (3) in the light of this background, examine the L.C. classification of the field and other classi-

${ }^{2}$ See also Peyton Hurt. "Staff Specialization: A Possible Substitute for Departmentalization." A.L.A. Bulletin 29:417-2I, July 1935-in which a similar method is offered. fication schemes of books and knowledge; (4) look over the college curriculum offerings to see what aspects of a subject are being taught formally; (5) consider who are the great authorities in the field and what books they have written that have been landmarks in the progress of the subject. With that background, the discussion of great books and authors may proceed more intelligently because there is some foundation upon which to build. Furthermore, you have an essential ingredient in all study - a realization of relationships. Too long, scholarship has analyzed and specialized to the point of infinity; we need badly to recapture the unity of knowledge to be able to synthesize. This is particularly urgent for the librarian who deals with the literature of subjects as a concomitant of a liberal education and not with the subject matter which the specialist should master.

An in-service program of study to acquire a knowledge of books will be of greater educational value to both the individual staff member and to the productive work of the library staff if it is broadened beyond the reading and discussion of great books to a consideration of the literature of specific subject fields. Those subject matter specialists who may be on the library staff may or may not know sufficiently the bibliographic sources of their subjects; other well-educated staff members may know books fairly well; but, by and large, all need refresher courses.

Such a program as envisioned here will have, if planned and executed with intelligence and enthusiasm, certain advantages over a subject course, except one in a foreign language taken by a staff member in the university. Curricula as now presented in most college catalogs offer practically no courses concerned with the literature of a subject and its development as based on the printed sources. To say this is not in the 
least to discount the importance of a librarian's being a subject matter specialist; it simply tries to draw attention to the fact that few librarians are subject specialists and even if they are that does not indicate a knowledge on their part of the bibliographic sources and literature of their fields. Then it seems reasonable, perfectly possible, and earnestly desirable for such a staff group-study plan to be developed in college and university libraries.

Librarians should cease proclaiming that library schools are to blame for this lack of special subject knowledge on the part of the school graduates. The schools have to admit the best of the applicants who seek entrance. If the science, social science, and art majors are not attracted to librarian- ship, who is to blame? The schools cannot supply training in these subjects, even if their faculties were equipped to do so. The only alternative, as Dean Reece suggests, is to get this knowledge either in college or after the library course. College and university librarians have a double responsibility in the matter: (I) to recruit more students with a greater variety of subject majors, (2) to develop sound in-service group-study programs to fill in this gap. The sooner, then, that librarians stop making the library schools their scapegoat and get down to business in fulfilling their own responsibilities, the more quickly will library staffs improve their educational foundation to meet the scholarly demands of college and university educational goals.

\section{The Graduate Student's Use of the Subject Catalog}

\section{(Continued from page 208)}

the student relied on the contents notes and any other bibliographical notes which furnished a clue to contents. The Library of Congress suggestions for subject headings were taken for contents notes by many of the students and were customarily considered in making selections of titles.

While the subject content of a book was the most important single consideration when the student was deciding which of the English titles he would select, those students who were familiar with their subjects or who had consulted bibliographies before coming to the catalog frequently chose certain titles because they recognized the author's name.

On the other hand, there were few who indicated that the date of the book influenced their choice. Some of those who did state a preference for recent books were studying subjects where the only material available had been published recently.
In summary, it can be said that the nature of the topic which the student was studying and the design of the catalog itself contributed to the dissatisfaction he experienced in using the subject catalog. The topical character of the subjects plus the fact that they frequently dealt with a limited area of a relatively undeveloped field made the periodical indexes a more fruitful source of references than the subject catalog.

Furthermore, the students, in trying to locate material through the subject catalog, were handicapped because they did not know precisely what it was the catalog was equipped to do nor the kind of material which could reasonably be expected to be listed in the subject catalog. Moreover, lacking experience and skill in the use of the catalog, they were not always able to find information which was readily available to them through the subject catalog. 